\title{
Сакральные предметы и трансформации музейной этики: истоки, проблемы, решения
}

\author{
Ксения В. Пименова \\ Национальный фонд научных исследований (FNRS); \\ Брюссельский свободный университет (ULB), Бельгия
}

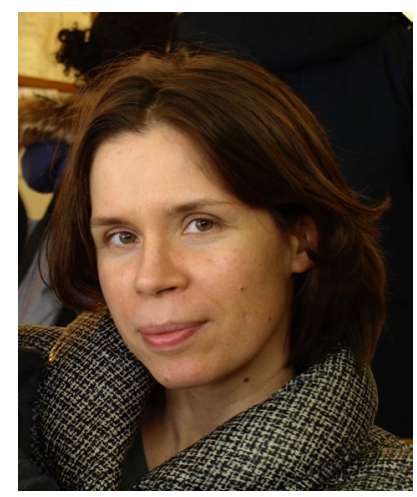

В статье рассматриваются основные аспекты проблематики сакральных предметов в музеях, анализируются политические и интеллектуальные причины трансформаций музейной этики на Западе, разбираются примеры сложностей музейной работы с сакральными предметами.

В первой части статьи резюмируются исторические причины маргинального положения, которое живая религия до недавнего времени занимала в музеях. Во второй и третьей частях анализируются факторы возрастающего присутствия религии в музее и трансформаций музейной этики в обращении с сакральными предметами в последние несколько десятилетий. Это, во-первых, деколонизация и связанное с ней переосмысление отношений между коренными народами и их наследием, а, во-вторых, эпистемологические сдвиги в социальных науках, которые с 1980-х годов формируют новое понимание музейных предметов как агентов социального мира. Таким образом, новая музейная этика опирается одновременно на принцип уважения к самим предметам и на признание за коренными народами прав на живые отношения со своим наследием, в первую очередь - «чувствительными материалами», к которым относятся культовые предметы, а также человеческие останки. Тем не менее, внедрение этих принципов в работу музеев на практике нередко выявляет противоречия между универсалистскими ценностями музейного дела (например, сохранением наследия и обеспечением доступа к нему) и партикуляристской логикой религиозных и этнических групп. В четвертой части статьи на конкретных примерах описываются сложности, с которыми западные музеи сталкиваются в вопросах экспонирования, хранения и репатриации сакральных предметов, а также возможные пути их решения.

В заключении отмечается особая роль региональных и республиканских музеев России в переосмыслении места религии в музее и во внедрении принципов этичного обращения с сакральными предметами.

Ключевые слова: сакральные предметы; музейная этика; деколонизация; религии коренных народов; поворот к вещзам; биографии вещей; экспонирование; репатриация; хранение; культурное наследие тронный ресурс] // Новые исследования Тувы. 2019, № 2. URL: https://nit.tuva.asia/nit/article/view/851 (дата обращения: дд.мм.гг.). DOI: 10.25178/nit.2019.2.10

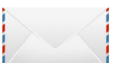

Пименова Ксения Викторовна - кандидат исторических наук, доктор социологии (PhD), постдокторантка Национального фонда научных исследований (Бельгия); сотрудница Лаборатории антропологии современных миров в Свободном университете Брюсселя (Бельгия). Адрес: K. Pimenova, Université libre de Bruxelles, LAMC - Secrétariat, CP 124, Av. F. Roosevelt 50, 1050 Bruxelles, Belgique. Эл. адрес: ksenia.pimenova@ulb.ac.be

Pimenova Ksenia Victorovna, Candidate of History, PhD in Sociology, Postdoctoral researcher, National Fund for Scientific Research (Fonds National de la Recherche Scientifique, FNRS); affiliated to Laboratoire d'Anthropologie des Mondes Contemporains (LAMC) at Free University of Brussels (ULB), Belgium. Postal address: Université libre de Bruxelles, LAMC - Secrétariat, CP 124, Av. F. Roosevelt 50, 1050 Bruxelles, Belgique.E-mail: ksenia.pimenova@ulb.ac.be 


\title{
Sacred objects and transformations of museum ethics: origins, problems, solutions
}

\author{
Ksenia V. Pimenova \\ National Fund for Scientific Research (FNRS); Free University of Brussels (ULB), Belgium
}

The article deals with the problematic of sacred objects in museums. It analyzes the political and intellectual reasons for the transformation of museum ethics in Western countries, and provides examples of the difficulties in dealing with sacred objects.

The first section of the article summarizes the historical reasons for the marginal position museums had until recently allocated to religion as a living phenomenon. The second and third sections analyze the reasons for the growing presence of religion in Western museums in the last few decades: first, the rethinking of the relationship between indigenous peoples and their heritage within the framework of decolonization; and, second, the epistemological shifts in the social sciences that have shaped a new understanding of "museum pieces" as social agents. The new museum ethics is therefore based on both the principle of respect for the objects themselves and the recognition of indigenous peoples' rights to a living relationship with their heritage, especially with "sensitive materials", such as religious objects and human remains. Nevertheless, implementing these principles often reveals contradictions between the universalist values of museum work, such as the conservation and the access to heritage, and the particularistic logic of religious and ethnic groups.

The fourth part of the article provides examples of some of the difficulties encountered by Western museums in exhibiting, storing and repatriating sacred objects, and describes how they have been dealt with.

Finally, the conclusion elaborates on the special position of regional museums in Russia's autochthonous republics in rethinking the religion in museum space and in implementing new museum ethics in dealing with sacred objects.

Keywords: sacred objects; museum ethics; decolonization; indigenous religions; ontological turn; biographies of things; museum display; storage; repatriation; cultural heritage

\section{Введение}

Отношения между религией и музеями - относительно новая тема в западных социальных науках и музееведении (Grimes, 1992; Minucciani, 2013; Paine, 2013). Теоретические и практические аспекты этих отношений обсуждаются в Северной Америке, Австралии и Европе в связи с репатриацией наследия коренных народов, этикой хранения и экспонирования сакральных предметов и человеческих останков (Jenkins, 2011; O'Neill, 2017; Turnbull, Pickering, 2010; Tythacott, Arvanitis, 2014). Мы привыкли считать музей пространством конфессионально нейтральным и свободным от присутствия религии. Действительно, живое присутствие религии, выражаемое в том числе через эмоции посетителей и сотрудников, через их отношения с сакральными предметами, до недавнего времени было в музее маргинальным и выглядело несколько неуместным. Причины вытеснения религии за пределы музейного мира коренятся в институциональных и интеллектуальных истоках музеев и в принципах репрезентации предметов в экспозиции через их эстетизацию и дистанцирование.

Однако в последние два-три десятилетия некоторые западные и в меньшей степени российские музеи становятся новыми локусами присутствия религии в общественном пространстве. Некоторые музеи, иногда сами того не желая, притягивают религиозные практики и должны формировать свою позицию в их отношении. Другие музеи вовлечены в процессы репатриации сакральных предметов и человеческих останков в качестве отдающей или принимающей стороны. Третьи сталкиваются с необходимостью выработки правил обращения с сакральными предметами и создают для них отдельные пространства. 
НОВЫЕ ИССЛЕДОВАНИЯ ТУВЫ

www.nit.tuva.asia

Первой задачей статьи является анализ политических и эпистемологических причин растущего присутствия религии в музее и трансформаций музейной этики. С одной стороны, как будет показано ниже, процессы деколонизации на Западе затрагивают музеи и приводят к более симметричным, чем ранее, отношениям культурных институций с коренными народами. С другой стороны, эпистемологические сдвиги, которые происходят с 1980-х годов в социальных науках, приводят к пересмотру субъектнообъектной дихотомии и формируют новое понимание предметов как агентов социального мира, наделенных собственными «биографиями» и правами. Сакральные предметы коренных народов занимают особое место в трансформациях музейной этики, поскольку отсылают к наследию колонизации и требуют соблюдения особенных правил обращения с ними.

Новая музейная этика на Западе охотно декларирует моральную ответственность музеев перед коренными народами и уважение к предметам их культурного наследия. Однако применение этих принципов на практике нередко наталкивается на сложности, вызванные противоречиями между универсалисткими ценностями музеев и партикуляристской перспективой этнических и религиозных групп. Второй задачей статьи, таким образом, является анализ некоторых сложных вопросов изучения, экспонирования, хранения и репатриации сакральных предметов.

Основной источниковой базой для данной статьи послужили антропологические и музееведческие научные публикации о работе с сакральными предметами на английском и французском языках. Отдельные примеры относятся к авторским материалам, собранным в ходе этнографической полевой работы в 2017 г. в Национальном музее им. А. В. Анохина Республики Алтай (г. Горно-Алтайск).

\section{Религия в музеях: эстетизация и дистанцирование}

Институциональная модель современных публичных музеев как на Западе, так и в России восходит к европейской эпохе Просвещения с ее идеей главенства разума и науки над верой (Buggeln, Paine, Plate, 2017). Науки и искусство, которые доказывали прогресс человечества, оказались главными двигателями развития музеев, тогда как религии отводилось второстепенное место экзотического курьеза. Неслучайно музеи религии и религиозной истории редки как в Европе, так и в России ${ }^{1}$

Конечно, музеи и в прошлом экспонировали сакральные предметы, однако собственно религиозные отношения с музейными предметами оказывались неуместными. В большинстве музеев основными стратегиями презентации сакральных предметов до сих пор чаще всего остаются их эстетизация или их дистанцирование от публики во времени и в пространстве. Примером эстетизации являются иконы, которые из объектов почитания переквалифицируются в предметы древнерусского искусства. Их экспонирование подчинено искусствоведческой перспективе и акцентирует различия между школами иконописи и особенности изобразительной техники, а не богословские и обрядовые вопросы. Что касается этнографии коренных народов, то дистанция между посетителем и сакральными предметами встроена в саму природу экспонирования, которое вырезает предмет из контекста и работает как «искусство отстранения» в пространстве и времени (Kirschenblatt-Gimblett, 1998). В силу колониальной истории своих коллекций и идей эволюционизма, часто лежащих в основе музейной презентации предметов, крупные этнографические музеи как на Западе, так и в России продолжают материализовывать культурную и временну́ю дистанцию между «нами» и «другими». В советских музеях сакральные предметы иллюстрировали культуру этнических групп, находящихся в процессе преодоления старых общественных отношений, и экспонировались как предметы прошлого (Hirsch, 2005; Teryukova, 2014).

Сегодня жесткая оппозиция между разумом и верой расценивается как фаза в истории идей, а не как адекватный инструмент для анализа социального мира. Но она продолжает влиять на иерархию музеев в восприятии публики. Не секрет, что наиболее «благородными» музеями, лучше всего отражающими достижения человечества, остаются для широкой общественности музеи искусства и науки, а не музеи религии или этнографии. Эта же оппозиция до сих пор способствует вытеснению религии как живого феномена за пределы музейного мира.

\section{Трансформации музейной этики в контексте деколонизации}

Тем не менее, за последние несколько десятков лет место религии в музеях постепенно меняется. Первым фактором этих трансформаций стал пересмотр отношений между колониальными державами

${ }^{1}$ Например, музей Св. Мунго в Глазго, музей истории религии в Санкт-Петербурге, музей Реформы в Женеве. 
и колонизированными народами. Критика колониального наследия и колониальных отношений коснулась и музеев, коллекции которых отражают историю присвоения наследия и его перемещения от периферий к центрам империй (Bennett, 2018). Это присвоение происходило как в результате насилия и карательных операций, так и через торговлю и обмен, этичность которых сегодня часто вызывает сомнения. Научные знания, лежащие в основе музейной классификации предметов, также содержат колониальный след, поскольку основаны на несимметричных отношениях между «экспертами» и «профанами», среди которых оказались сами носители этнических и религиозных традиций (Баранов, 2016: 50).

Деколонизация музеев сегодня является важной проблематикой западной музеологии и антропологии (Chambers, De Angelis, 2014; Lonetree, 2012; Stanley, 2007). Она предполагает, во-первых, пересмотр иерархических отношений между метрополиями и перифериями по вопросам собирания и обращения с наследием. Именно поэтому важной частью музейной этики становятся исследования провенанса (происхождения) предметов и прозрачная коммуникация вокруг истории коллекций. Во-вторых, деколонизация музеев также означает уважение к самим предметам с точки зрения их включенности в отношения с современными группами. В случае сакральных предметов важно понять, какие запреты и правила поведения действуют в их отношении, чтобы по возможности вписать эти правила в музейный контекст. Наконец, деколонизация музеев также ставит вопрос о юридической и символической собственности на культурное наследие и сакральные предметы.

Одна из первых работ, описывающая постколониальную рефлексию внутри музея, - глава «Музеи как контактные зоны» Дж. Клиффорда (Clifford, 1997). Наблюдая встречу между сотрудниками Музея искусств Портленда (Орегон) и представителями тлингитских кланов в 1989 г. по вопросу обновления экспозиции, он заметил, что тлингиты не «созерцают» музейные предметы, а используют их как поводы для исполнения песен и рассказывания историй. Истории и мифы, вызванные к жизни старинными клановыми предметами, при этом «интерпретируются как истории специфические, указывающие на современные политические конфликты» (там же: 190). Иными словами, между предметами и коренными народами существуют текущие отношения, которые музей не может игнорировать. Признание этих отношений должно стать толчком к переосмыслению стратегий экспонирования предметов и в более общем плане - общественной роли музеев. С этой точки зрения музеи определяются как «хранители» (guardians) наследия, которое может быть собственностью музея в юридическом смысле, а в символическом - принадлежит коренным народам.

Разделенная с коренными народами ответственность за хранение (shared guardianship) стала одной из центральных концепций музейной этики. Она означает, что музеи несут моральную ответственность за правильное обращение с наследием перед конкретными коренными народами (source communities), а не только перед своими головными институциями, аудиторией или абстрактным человечеством. Этот этический сдвиг зафиксирован юридически в США, где в 1990 г. был принят закон NAGPRA («O защите захоронений американских индейцев и репатриации» - англ. Native American Graves Protection and Repatriation Act). Согласно этому закону, музеи и другие публичные институции, хранящие индейские сакральные предметы и человеческие останки, обязаны инвентаризовать коллекции и информировать об их содержании. Они также должны консультироваться с представителями индейских общин по вопросам экспонирования и удовлетворять требования репатриации. В Канаде и в Австралии не существует подобных законов, однако принцип разделенной ответственности давно вошел в музейную практику через рекомендации и этические кодексы национальных музейных ассоциаций. Рекомендации международного Совета Музеев (англ. International Council of Museums, сокр. англ. ICOM) определяют сакральные предметы и человеческие останки как «чувствительные материалы», предписывают уважение к ним и учет интересов и мировоззрения этнических и религиозных групп (статьи 2.5, 3.7 и 4.3 см.: Этический кодекс ..., Электр. ресурс).

Эти рекомендации одновременно фиксируют изменение профессиональных норм и стимулируют дальнейшую рефлексию о практическом применении музейной этики (Kreps, 2015; Marstine, 2011). Сотрудничество музеев с коренными народами в целом идет уже несколько десятков лет. Оно выражается в совместной работе в музейных фондах для изучения коллекций; в организации выставок и обновлении постоянных экспозиций; в создании интернет-платформ для цифровой репатриации (см. о ней ниже). Такие проекты ревитализируют культуру и религиозные практики, а также стимулируют взаимовыгодный обмен между экспертным знанием и живыми знаниями коренных народов. 


\section{Сакральные предметы в зеркале социальных наук}

Вторая причина трансформации музейной этики в отношении культурных артефактов и особенно сакральных предметов - эволюция научных парадигм. С 1980-х годов в социологии и социальной антропологии возникают разные теоретические подходы, которые вместе иногда квалифицируются как онтологический поворот (Соколовский, 2016). Их общая черта - отказ от строгих дихотомий (субъект / объект, человек / природа, тело / разум, одушевленное / неодушевленное, человеческое / нечеловеческое). Эти подходы рассматривают предметы не только и не столько как свидетельства прошлого, а как активную и симметричную часть социального мира, неотделимую от человека и на него похожую. Как известно, во многих культурах предметы наделяются качествами личности (именем, полом), а иногда «сливаются» с человеком настолько, что поддерживают социальный статус прежнего владельца даже после обмена (Munn, 1986). Некоторые авторы говорят об агентности вещей, то есть их способности действовать (Gell, 1998). Вещи также обладают биографиями, которые переплетены с биографиями индивидов и историей социальных групп (Hoskins, 1998; Kopytoff, 1986). Материалы, из которых сделаны вещи, определяют функциональные и символические свойства в мире людей (Ingold, 2011: 19-32). Вещи и люди зависят друг от друга и «сплетены» отношениями собственности, привязанности, взаимовыручки (Hodder, 2012).

Сакральные предметы дают этим подходам богатый материал. Как и все остальные вещи, сакральные предметы социализированы на разных этапах своего жизненного цикла. Кроме того, они связаны с невидимыми, но влиятельными социальными акторами - божествами, защитниками, духами. Если обратиться к сибирской этнографии, яркими биографиями и агентностью наделены шаманские атрибуты, в частности бубны (Анохин, 1924; Потапов, 1997). Бубны ритуально оживлялись, становясь вместилищами духов и ездовыми животными шаманов, а после смерти владельцев как правило «дезактивировались» путем разрезания мембраны. Добровольно-принудительная сдача бубнов в советские музеи становилась новым этапом в их биографии и продлевала их жизнь. Однако она также разрывала прежние социальные связи предметов и выводила их из среды их использования, превращая в предметы наследия.

В теоретических дискуссиях о музеификации сакральных предметов выделяются две противоположные позиции. Первая отводит ведущую роль музейному контексту, который полностью или частично уничтожает прежние сакральные смыслы (Dudley, 2012; Kreinath, 2015).

«Архитектурное и концептуальное пространство, в котором живут предметы, может радикально менять или определять их значение, его восприятие публикой. Священные предметы в синагогах, храмах и церквях - это одно; они же в музеях и галереях искусства - совсем другое. Даже если “экзегетическое” значение предметов (то, что о них говорят) оставалось бы неизменным, их контекстуальное значение, их пространственное и концептуальное соотношение с другими символами неминуемо меняется» (Grimes, 1992: 419).

С позиций биографии вещей музеификация - это вторжение в жизнь предмета, «сопоставимое с порабощением или с захватом пленников» (там же: 425). Цель сохранения наследия, которой подчинена деятельность музеев, навсегда «замораживает» его биографию. Это касается и тех сакральных предметов, которые в традиции создаются для однократного использования, а затем намеренно выбрасываются или уничтожаются, как маски маланган, использующиеся в церемониях проводов умерших у народов Папуа Новой Гвинеи (Küchler, 2002). По той же логике сохранения наследия, музей оставляет доступным для посетителей только визуальный канал коммуникации с сакральными предметами, тогда как их тактильное, звуковое, обонятельное восприятие, столь важное во многих религиях, как правило оказывается невозможным (Buggeln, Paine, Plate, 2017).

С другой стороны, предметы иногда оказываются сильнее контекста, и именно через них религия проникает в музеи вопреки духу времени, целям музея и концепции экспозиции. В 1930-е годы посетители продолжали молиться иконам, выставленным в Музее истории религии в Ленинграде, несмотря на активные антирелигиозные кампании того времени и стремление музейщиков экспонировать религию как факт прошлого (Teryukova, 2014). Иногда сакральные смыслы вообще возникают самостоятельно даже у тех предметов, которые никогда не были задействованы в религиозных обрядах. Так произошло с картиной Сальвадора Дали «Тайная вечеря» (Sacrament of the Last Supper), которая хотя и интерпретирует христианский сюжет, создавалась художником как предмет искусства, а не почитания. Картина привлекает посетителей, которые молятся перед ней и делают ей подношения, несмотря на то, 


\section{НОВЫЕ ИССЛЕДОВАНИЯ ТУВЫ}

www.nit.tuva.asia

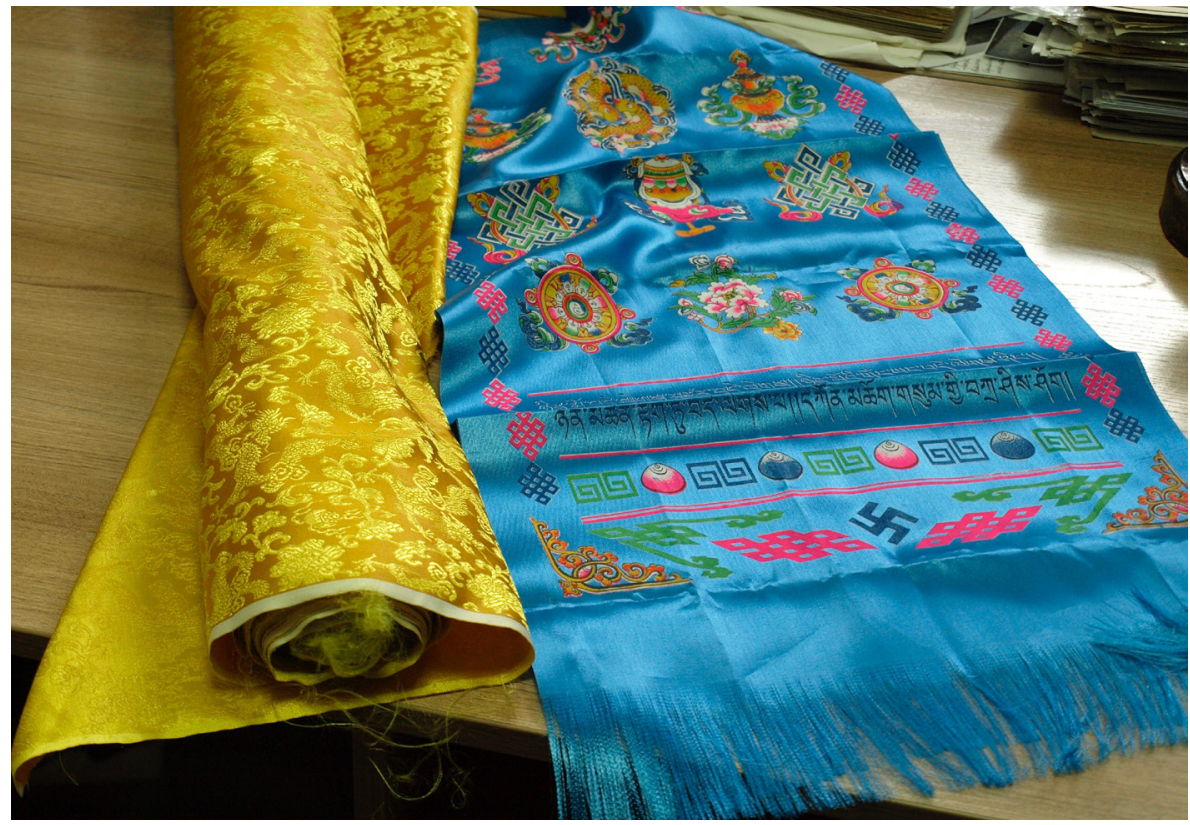

Фото 1. Церемониальные шелковые шарфы (алт. кадаки), подаренные «Укокской принцессе». Национальный музей им. А. В. Анохина Республики Алтай (Горно-Алтайск). Фото автора, 20172.

Photo 1. Ceremonial silk scarves (kadak) offered to the "Ukok Princess". Anokhin National Museum of Altai Republic. Photo by author, 2017. что Национальная галерея искусств (Вашингтон) старается препятствовать ее прочтению в религиозном ключе, поскольку оно не отвечает целям этого музея (Buggeln, Paine, Plate, 2017).

В других случаях музеификация увеличивает популярность предметов и расширяет их семантику. Здесь интересна история Улуг Хуртуях Тас (Большой каменной старухи), изваяния окуневской культуры (III тысячелетие до н. э.), которое издавна почиталось жителями Аскизского района Хакасии как средство исцеления от бесплодия (Самушкина, 2009: 109-113). В 1954 г. изваяние было вывезено из Аскизской степи в Хакасский республиканский краеведческий музей в Аба-

кане, в котором почитание и кормление продолжались в течение нескольких десятилетий. В 2003 г. изваяние было возвращено в Аскизский район, и это событие торжественно отмечалось в присутствии республиканских политиков как праздник родов хакасского народа. Музеификация в советском Абакане, а позже возвращение в Аскиз, превратили изваяние из объекта узкофункционального местного поклонения в символ духовного и культурного возрождения всей Хакасии.

Кажется, что противопоставлять стирание религиозного смысла и его реактуализацию не имеет смысла. Судьба конкретных сакральных предметов в музеях на деле развивается разными путями. Она зависит не только от свойств самого предмета и позиции музея в отношении религии, но и от политических и институциональных факторов. Во-первых, деколонизация на Западе и этнокультурное возрождение в России притягивают общественное внимание к культурному наследию. Эти политические процессы делают более осязаемыми для публики сакральные смыслы предметов и легитимируют религиозные отношения в музейном пространстве. Во-вторых, на восприятие предмета влияют направленность музея, его отношения с идентичностью посетителей. Представляется, что в региональных музеях и культурных центрах коренных народов посетители чаще и легче вовлекаются в религиозные отношения с сакральными предметами, потому что уже обладают опытом взаимодействия с подобными предметами вне музея и представлениями об их истории и свойствах. Привилегированные отношения музея с культурой, которая создала предмет, объясняют разницу между шаманским костюмом в Музее истории Бурятии им. М. Н. Хангалова (Улан-Удэ), притягивающим подношения, и тофаларским шаманским костюмом в Музее набережной Бранли в Париже, который всегда «молчит». То же касается некоторых археологических человеческих останков. Если посетители наделяют их особенным статусом и свойствами (например, способностью наносить вред или помогать), то возможно возникновение практик избегания или почитания, как это произошло с мумией «Укокской принцессы» после ее возвращения в Национальный музей им. А.В. Анохина (Горно-Алтайск) в 2012 г. (см. фото 1 u 2 ).

\section{Трансформации музейной этики: исследования провенанса, экспонирование, репатриация}

Процессы деколонизации и эпистемологические сдвиги в социальных науках имеют прямое отношение к трансформациям музейной этики и связаны между собой. Ниже будут рассмотрены несколько примеров из западной музейной практики, относящихся к исследованиям, экспонированию (и хранению) сакральных предметов, а также их репатриации. 


\section{НОВЫЕ ИССЛЕДОВАНИЯ ТУВЫ}

\author{
www.nit.tuva.asia
}

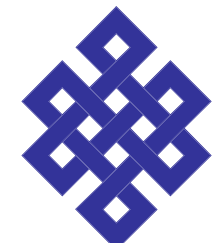

Исследования провенанса предметов и прозрачная коммуникация вокруг истории отдельных предметов и коллекций декларируются как приоритетная задача во многих музеях и культурных институциях. Они позволяют проследить движения предметов в пространстве и в «большой» истории, которую важно знать музейной аудитории и широкой общественности. Эта масштабная задача редко осуществляется одними музеями, чаще - в рамках проектов, объединяющих сотрудников музеев с историками, этнографами и искусствоведами. Такие исследования позволяют заглянуть в историю колониального насилия, ограблений, продажи на черных рынках, и наконец попадания предметов в музеи, которое «легитимирует» их сомнительный провенанс. ${ }^{1}$ В российских реалиях изучение истории коллекций сакральных предметов могло бы пролить свет на региональную историю советских антирелигиозных кампаний, в которой остаются белые пятна.

Применение музейной этики на практике нередко вступает в противоречие с универсалистскими принципами, лежащими в основе работы музеев: например, с бессрочным сохранением наследия ради будущего всего человечества и с обеспечением доступа к предметам. Одна из потенциально чувствительных областей музейного дела - экспонирование сакральных

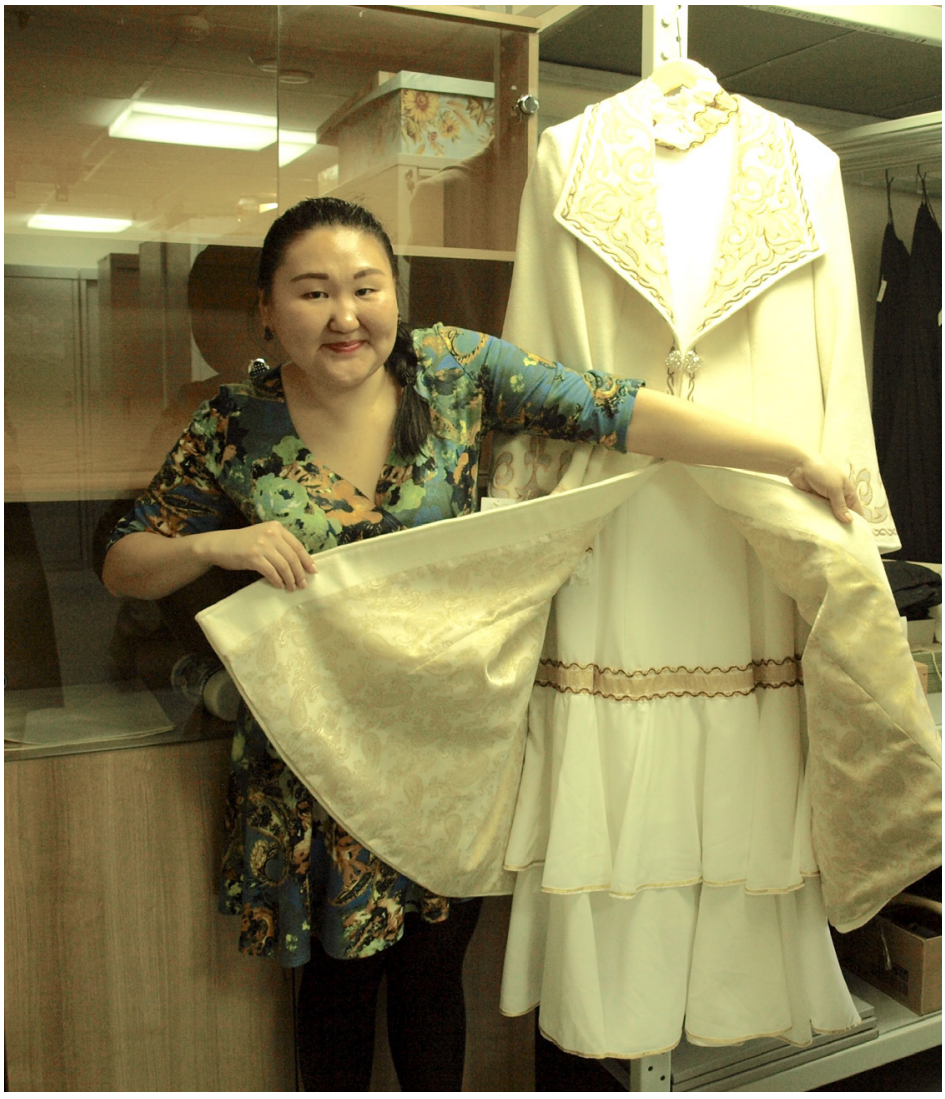

Фото 2. Сотрудница Национального музея им. А. В. Анохина Республики Алтай (Горно-Алтайск) А. Аргокова показывает платье и пальто из женского костюма, привезенного в дар «Укокской принцессе» посетителем из Казахстана. Шелк, войлок. Фото автора, 2017 г. Photo 2. An employee of the Anokhin National Museum of Altai Republic (Gorno-Altaisk) A. Argokova shows women's dress and coat offered to "Ukok Princess" by a visitor from Kazakhstan. Silk, felt. Photo by author, 2017. предметов. Музеи допускают к предметам всех посетителей, не диффиренцируя их по этническим, клановым или половозрастным категориям. Однако если в христианстве и буддизме нет ограничений на осмотр сакральных изображений (икон в христианстве и тханк в буддизме), то в других случаях недифференцированное экспонирование вступает в противоречие с религиозными представлениями коренных народов.

Самым ярким примером табуированных предметов, которые требуют пересмотра стратегий экспонирования, являются чуринга (churinga, tjurunga) - секретно-сакральные предметы, хорошо известные в антропологии благодаря Э. Дюркгейму. Чуринга - круглые или продолговатые камни или куски дерева с нанесенными на них рисунками, кодирующими секретную информацию, связывают индивида с тотемом клана, с предками, духами и территорией традиционного проживания рода. Аборигены Австралии прячут их в тайных местах и достают на время клановых церемоний. Чуринга также определяют права клана на землю, и с 1970-х гг. австралийское законодательство признает их как полноценные документы в судебных процессах. Учитывая эти свойства, открытое экспонирование чуринга не только неэтично, но и чревато втягиванием музеев в политико-юридические конфликты между отдельными аборигенными группами по поводу владения землей и ее недрами. Секретный характер чуринга не только налагает ограничения на экспонирование, но и ставит перед музейными сотрудниками и учеными вопросы об этике музейного хранения. Многие австралийские, а затем и европейские музеи, уже с 1980-х гг. начали снимать свои коллекции секретно-сакральных предметов с экспозиции и организовывать для них отдельное хранение с ограниченным доступом, куда можно заходить нескольким сотрудникам и членам соответствующих кланов (Batty, 2016).

${ }^{1}$ См., например, проект Translocations: Histotical Enquieries into the Displacement of Cultural Assets: http://www.translocations.net/en/project/ 
Конечно, отказ от экспонирования - радикальная стратегия, в которой уважение к самому предмету и к коренным народам, которые его создали, выводит предметы из общего доступа. Однако она касается далеко не всех сакральных предметов. В зависимости от свойств предметов возможны другие этичные сценарии. Например, у канаков Новой Каледонии широко распространено использование магических камней для обрядовых задач как положительного, так и отрицательного характера (войны, колдовство). В отличие от чуринга, магические камни не содержат секретной информации, но считаются вместилищем духов, которые могут нанести вред всем, кто смотрит на них или трогает их без соответствующей инициации. К счастью, в канакской традиции широко практикуется ритуальная «дезактивация» магических камней. В культурном центре Жан-Мари Тьибао (Нумеа, Новая Каледония) их экспонирование стало возможным благодаря предварительно проведенным обрядам выселения духов. Камни превратились из магических предметов в культурные артефакты, которые не пугают посетителей и хранителей музея (Kasarhérou, 2016).

Другие сакральные предметы требуют не «дезактивации», а соблюдения определенных правил поведения. Например, погребальные статуи рамбарамn (архипелаг Вануату) моделировались из глины и листьев по телу умершего, украшались его прижизненными регалиями (клыками кабана, раковинами) и содержат внутри его череп, который считается вместилищем души. Рамбарамп изготовлялись только для мужчин, достигших высших степеней инициации, и хранились в мужских церемониальных домах, откуда изредка выносились в деревню, участвуя в коллективных обрядах наравне с ее жителями. Статуи репрезентируют покойного как живого человека, воплощают высокий социальный престиж индивида и более общем смысле - высокий статус мужчин по сравнению с женщинами, которые не должны смотреть на рамбарамп сверху вниз. Экспонирование рамбарамп стремится по возможности учитывать эти традиционные гендерные иерархии, поэтому в некоторых музеях статуя поднимается таким образом, чтобы уровень ее глаз был выше среднего роста посетительниц. Специальные правила применяются и для хранения статуй. Вертикальное положение, в котором традиционно хранились эти статуи и которое наиболее соответствует этике обращения с «предметами-личностями», опасно в силу их хрупкости, поэтому статуи размещаются наклонно (Del Re, Countryman, 1995: Электр. pecypc).

Одна из возможных стратегий этичного экспонирования сакральных предметов - создание полузакрытых экспозиционных пространств. По такому пути, например, пошел Музей набережной Бранли в Париже, выставляя рамбарамп в затемненном боксе с узким коридором. Посетитель сначала узнает информацию об этих экспонатах, а потом самостоятельно выбирает между осмотром и отказом от него. Сходные стратегии, предлагающие посетителю информированный выбор, применяются при экспонировании человеческих останков, которые во многом сходны с сакральными предметами с точки зрения музейной этики (Jenkins, 2011).

Новая этика иногда также вступает в противоречие с принципом неделимости коллекций и целями сохранения наследия. Несмотря на общественную риторику и политику деколонизации, одной из тем, болезненных для музейного сообщества, является возвращение культурных артефактов, сакральных предметов и человеческих останков коренным народам. Хотя репатриация останков с последующим захоронением очень распространена, она не всегда ведет к нему автоматически. Иногда наиболее этичным компромиссом между хранением и репатриацией представляется дифференцированный подход, различающий идентифицированные и неидентифицированные останки. Такой путь был выбран при репатриации из австралийских, американских и европейских музеев mokomokai - высушенных человеческих голов, в которых по представлениям новозеландских маори хранится жизненная сила человека и рода. В XIX в. mokomokai стали объектами коллекционного бума, что привело не только к массовым продажам голов уже умерших людей, но с большой вероятностью - к казням неизвестных пленников. В случаях, когда провенанс и генетические исследования позволяют установить связь с современными родовыми группами, mokomokai передаются им для перезахоронения. Для неидентифицированных mokomokai в музее Те Папа Тонгарева (Веллингтон) создано сакральное пространство с ограниченным доступом, в котором они хранятся для дальнейшего изучения (Alderton, 2014). В России репатриация археологических останков исключает их захоронение и проходит по сценарию музеификации. Возвращения мумии «Укокской принцессы» в Национальный музей им. А. В. Анохина Республики Алтай (Горно-Алтайск) и останков «Царской четы» в Национальный музей им. АлдынМаадыр Республики Тыва (Кызыл) могут рассматриваться как компромиссные сценарии, в которых сохранение наследия не исключает будущих исследований и сочетается с идеей возвращения «домой». Осмотр «Укокской принцессы» считается у алтайцев неэтичным, поэтому экспонирование ограничено несколькими днями в месяц, что оставляет за посетителями право выбора. 
Более сложным вопросом оказывается репатриация сакральных предметов. Практика в этой области мозаична и зависит от политики стран и отдельных музеев. В США, Австралии и Канаде сакральные предметы давно и регулярно передаются на постоянное или временное хранение в ассоциации, музеи и культурные центры коренных народов. Репатриация же сакральных предметов из Европы в другие страны пока касается только отдельных предметов и достаточно редка. Среди предметов, переданных индейцам лакота из Музеев Глазго, «рубаха духов» (Ghost Dance Shirt), священный атрибут религии пляски духа, индейского мессианского движения конца XIX века. Требования репатриации были удовлетворены только тогда, когда исследования провенанса подтвердили, что рубаха была снята с погибшего участника бойни при Вундед-Ни в 1890 г., в котором лакота потерпели сокрушительное поражение. На решение о репатриации здесь повлияло в большей степени значение этой битвы для народа лакота и связь со смертью, чем собственно сакральный характер предмета. При репатриации была достигнута договоренность о бессрочном хранении и передачи предмета в будущем для временных выставок в Глазго (Curtis, 2010: 237).

Говоря о репатриации, нельзя не упомянуть нашумевший в музейной среде доклад французского искусствоведа Бенедикт Савуа и сенегальского экономиста Фельвина Сарра «О реституции африканского культурного наследия. К новым этическим отношениям» (Sarr, Savoy, 2018: Электр. ресурс). В докладе представлены результаты масштабной инвентаризации африканских коллекций в государственных музеях Франции и предлагается «дорожная карта» репатриаций. Кандидатами на первый этап репатриации определяются военные трофеи колониальных кампаний, а также предметы, вывезенные из Африки на временные выставки и не возвращенные. Речь идет о высоко символичных артефактах общим числом около 25 наименований, в отношении которых уже давно сформулированы официальные требования репатриации. Это королевские регалии и священные предметы (маски, культовые статуэтки боли, детали алтарей) из Бенина, Нигерии, Сенегала, Эфиопии, Мали и Камеруна. Доклад не рекомендует репатриацию законно приобретенных предметов и предписывает дальнейшее изучение и инвентаризацию в случаях сомнительного провенанса. Он также предполагает предварительную оценку состояния принимающих музеев в Африке для определения условий хранения предметов.

Доклад Савуа-Сарр также предлагает программу по развитию так называемой цифровой репатриации - созданию баз данных о предметах материального наследия. В отличие от репатриации физической, цифровая репатриация является передачей не самих предметов, а только документации, аудиозаписей, фото- и видео изображений. Интересно, что после цифровой репатриации правила обращения с информацией и изображениями выстраиваются с учетом сакральности, секретности и опасности оригинальных предметов (De Largy Healy, 2011). Цифровая репатриация является еще одним вариантом компромисса между сохранением предметов, принципом неделимости коллекций и новой музейной этикой.

\section{Заключение: музейная этика в республиканских музеях России}

Многие аспекты этического обращения с сакральными предметами не могут бытьпроанализированы в рамках этой статьи. Приведенные здесь примеры отражают лишь основные тенденции в обращении с сакральными предметами, значимыми культурными артефактами и человеческими останками в музеях Европы, Северной Америки и Австралии.

Ситуация в России во многом иная. В жизни музейного сообщества на повестке дня на первом месте стоят вовсе не деколонизация и музейная этика, а другие вопросы бюрократического, финансового, юридического характера. Идея деколонизации не поддерживается законодательно, не является частью культурной политики и практически отсутствует в общественных дебатах о культурном наследии коренных народов России. Отдельные прецеденты репатриации человеческих останков в музеи Тувы и Алтая являются на этом фоне исключениями, а не правилами. Тем не менее, процессы этнокультурного и этнорелигиозного возрождения, которые идут в национальных республиках России с 1990-х годов, имеют структурные сходства с движениями коренных народов Америки и Австралии. В сибирских республиках интеллектуальные и культурные элиты и религиозные лидеры постепенно нормализуют идею культурного самоопределения местных сообществ. Важную роль в этих процессах играют республиканские музеи, такие, как Национальный музей им. Алдын-Маадыр Республики Тыва в Кызыле и Национальный музей им. А. В. Анохина Республики Алтай в Горно-Алтайске. 
Представляется, что важная роль в распространении новой музейной этики в российских реалиях будет принадлежать именно республиканским и краеведческим музеям. Подобно музеям и культурным центрам коренных народов Америки или Австралии, такие музеи в России отражают и формируют идентичность одной этнотерриториальной общности и гораздо сильнее включены в ее религиозную, культурную и этнополитическую жизнь, чем столичные музеи этнографии, представляющие наследие разных коренных народов. Местные музеи являются «музеями Себя» в отличие от «музеев Других» (de l'Estoile, 2007). Они хранят сакральные предметы только «своих» народов и экспонируют их местной публике, которая иногда еще помнит об их бытовании во внемузейном контексте. Сотрудники республиканских и краеведческих музеев - этнографы, искусствоведы, археологи - не только являются носителями академического знания, но социализированы с детства в своих этнокультурных и обрядовых традициях. Дистанция, с помощью которой «музеи Других» могут отгораживаться от религии, сводится здесь к минимуму, а актуализация религиозных смыслов предметов происходит более коротким путем. В силу своей природы именно местные музеи оказываются в выигрышной позиции с точки зрения внедрения музейной этики и могут адекватно адаптировать ее правила к особенностям религиозной жизни своих групп.

\section{Благодарности}

Благодарю дирекцию и сотрудников Национального музея им. А. В. Анохина Республики Алтай за предоставленную возможность провести полевые исследования в музее в 2017 г., а также Алевтину Соловьеву (РГГУ, Москва / Тартусский университет, Эстония) за ценную информацию о шаманском костюме в Музее истории Бурятии им. М. Н. Хангалова (Улан-Удэ).

\section{СПИСОК ЛИТЕРАТУРЫ}

Анохин, А. В. (1924) Материалы по шаманству у алтайцев. Л. : Издательство Российской академии наук. 248 р.

Баранов, Д. А. (2016) О чем молчат вещи // Российская антропология и «онтологический поворот» / С. В. Соколовский (ред.). М. : Институт этнологии и антропологии РАН. 404 с. С. 33-83.

Потапов, Л. П. (1997) Шаманский бубен - уникальный памятник духовной культуры тюркских народов Алтая // Этнографическое обозрение. № 4. С. 25-39.

Самушкина, Е. В. (2009) Символические и социо-нормативные аспекты современного этнополитического движения Республики Алтай, Республики Тыва, Республики Хакасия (конец XX - начало XXI в.). Новосибирск : Издательство Института археологии и этнографии СО РАН. 274 с.

Соколовский, С. В. (2016) Вместо введения. Теории вещей и этнографии материальности // Российская антропология и «онтологический поворот» / С. В. Соколовский (ред.). М. : Институт этнологии и антропологии РАН. 404 с. С. 3-30.

Этический кодекс ИКОМ для музеев [Электронный ресурс] // ICOM. URL: https://icom.museum/wp-content/uploads/2018/07/code_russia2013-1.pdf (дата обращения: 01.03.2019).

Alderton, Z. (2014) The Secular Sacred Gallery: Religion at Te Papa Tongarewa // Secularisation: New Historical Perspectives / Ch. Hartney (ed.) Newcastle upon Tyne : Cambridge Scholars Press. Pp. 251-264.

Batty, Ph. (2016) Problems associated with the management of secret / sacred objects in Australia: the Melbourne Museum Experience // Baessler-Archiv. Beiträge zur Völkerkunde. No 63. Pp. 11-16.

Bennett, T. (2018) Museums, Power, Knowledge. Selected Essays. London : Routledge. 340 p.

Buggeln, G., Paine, C., Plate, B. (2017) Religion in Museums. Global and Multidisciplinary Perspectives. London ; New York : Bloomsbury. 265 p.

Chambers, I., De Angelis, A. (2014). The Postcolonial Museum: the Arts of Memory and the Pressures of History. Farnham : Ashgate. 274 p.

Clifford, J. (1997) Routes. Travel and Translation in the Late Twentieth Century. Cambridge, Massachusetts : Harvard University Press. 416 p.

Curtis, N. (2010) Repatriation from Scottish Museums: Learning from NAGPRA // Museum Anthropology. No 33(2). P. 234-248.

de l'Estoile, B. (2007) Le Goût des Autres. De l'Exposition coloniale aux arts premiers. Paris : Flammarion. 454 p.

De Largy Healy, J. (2011) Pour une anthropologie de la restitution. Archives culturelles et transmissions des savoirs en Australie // Cahiers d'ethnomusicologie. No 24. P. 45-62. 
НОВЫЕ ИССЛЕДОВАНИЯ ТУВЫ

www.nit.tuva.asia

\section{THE NEW RESEARCH OF TUVA}

Del Re, Ch., Countryman, P. (1995) How would you mount a Rambaramp? [Элекронный ресурс] // American Institute for Conservation. Resources | Conservation Online. URL: http://resources.conservation-us.org/wp-content/uploads/ sites/8/2015/02/osg003-02.pdf (дата обращения: 01.03.2019).

Dudley, S. (2012) Museum Objects: Experiencing the Properties of Things. London : Routledge. 347 p.

Gell, A. (1998) Art and Agency. An Anthropological Theory. Oxford : Clarendon Press. 296 p.

Grimes, R. (1992) Sacred Objects in Museum Spaces // Studies in Religion / Sciences religieuses. No. 21(4). P. 419-430.

Hirsch, F. (2005) Empire of Nations. Ethnographic Knowledge and the Making of the Soviet Union. Ithaca : Cornell University Press. 392 p. $252 \mathrm{p}$.

Hodder, I. (2012) Entangled. An Archaeology of the Relationships between Human and Things. London : Wiley-Blackwell.

Hoskins, J. (1998) Biographical Objects. How Things Tell the Stories of People's Lives. New York ; London : Routledge. $213 \mathrm{p}$.

Ingold, T. (2011) Being Alive. Essays on Movement, Knowledge and Description. London : Routledge. 270 p.

Jenkins, T. (2011) Contesting Human Remains in Museum Collections. A Crisis of Cultural Authority. New York : Routledge. 174 p.

Kasarhérou, E. (2016). Indigenous perspectives on sacred objects and museums in Melanesia: the New Caledonia case // Baessler-Archiv. Beiträge zur Völkerkunde. No. 63. P. 24-28.

Kirschenblatt-Gimblett, B. (1998) Destination Culture. Tourism, Museums, and Heritage. Berkeley : University of California Press. 326 p.

Kopytoff, I. (1986) The cultural biography of things: Commoditization as process // The social life of things: commodities in cultural perspective / Appadurai, A. (ed.). Cambridge : Cambridge University Press. 339 p. Pp. 64-91.

Kreinath, J. (2015) Museality // R. A. Segal and Von Stuckrad, K. Vocabulary for the Study of Religion. Vol. 2 (F-O). Leiden : Brill. 1842 p. P. $481-486$.

Kreps, Ch. (2015) Appropriate museology and the "new museum ethics”. Honoring diversity // Nordisk Museologi. No 2. P. 4-16.

Küchler, S. (2002) Malanggan: Art, Memory and Sacrifice. London : Bloomsbury. 256 p.

Lonetree, A. (2012) Decolonizing Museums. Representing Native America in National and Tribal Museums. Chapel Hill : University of North Carolina Press. 248 p.

Marstine, J. (2011) The contingent nature of the new museum ethics // Routledge Companion to Museum Ethics. Redefining Ethics for the Twenty-First Century / Marstine, J. (ed.). London : Routledge. 486 p. P. 3-25.

Minucciani, V. (2013) Religion and Museums. Immaterial and Material Heritage. Torino : Umberto Allemandi. 110 p.

Munn, N. (1986) The Fame of Gawa. A Symbolic Study of Value Transformation in a Massim (Papua New Guinea) Society. Cambridge : Cambridge University Press. 331 p.

O'Neill, M. (2017) Museums and the Repatriation of Objects, 1945-2015 // Buggeln, G., Paine, C., and Plate, B. (eds.) Religion in Museums. Global and Multidisciplinary Perspectives. London-New York : Bloomsbury. 265 p. P. 99-109.

Paine, C. (2013) Religious Objects in Museums. Public Lives and Public Duties. London ; New York : Bloomsbury. 192 p.

Sarr, F., Savoy, B. (2018) The Restitution of African Cultural Heritage. Toward a New Relational Еthics [Электронный ресурс] // restitutionreport2018.com. URL: http://restitutionreport2018.com/sarr_savoy_en.pdf (дата обращения: 01.03.2019).

Stanley, N. (2007) Can Museums become Indigenous? The Asmat Museum of Culture and Progress and Contemporary Papua // Stanley, N. (ed.) The Future of Indigenous Museums. Perspectives from the Southwest Pacific. New York : Berghahn Books. 272 p. P. 190-204.

Teryukova, E. (2014) Display of religious objects in museum space. Russian museum experience in the 1920s and the 1930s // Material Religion. No. 10 (2). P. 255-258.

Turnbull, P., Pickering, M. (2010) The Long Way Home. The Meaning and Values of Repatriation. New York : Berghahn Books. 224 p.

Tythacott, L., Arvanitis, K. (2014) Museums and Restitution: New Practices, New Approaches. London ; New York : Routledge. 224 p.

Дата поступления: 15.03.2019 2.

\section{REFERENCES}

Anokhin, A. V. (1924) Materialy po shamanstvu u altaitsev. [Materials on shamanism among the Altai people]. Leningrad, Russian Academy of Sciences publ. 248 p. (In Russ.) 
Baranov, D. A. (2016) O chem molchat veshchi [What things keep silence on]. In: Rossiiskaia antropologiia $i$ «ontologicheskii povorot» [Russian anthropology and the 'ontological turn'] / ed. S. V. Sokolovskii. Moscow, Institute of Ethnology and Anthropology RAS. 404 p. Pp. 33-83. (In Russ.)

Potapov, L. P. (1997) Shamanskii buben - unikal'nyi pamiatnik dukhovnoi kul'tury tiurkskikh narodov Altaia [The shamanic drum, a unique item of spiritual culture of Turkic peoples of Asia]. Etnograficheskoe obozrenie, no. 4, pp. 25-39. (In Russ.)

Samushkina, E. V. (2009) Simvolicheskie i sotsio-normativnye aspekty sovremennogo etnopoliticheskogo dvizheniia Respubliki Altai, Respubliki Tyva, Respubliki Khakasiia (konets XX - nachalo XXI v.) [Symbolic and socionormative aspects of ethnopolitical movements of Republics of Altai, Tuva and Khakassia, late 20th to early 21st century]. Novosibirsk, Institute of Archaeology and Ethnography, Siberian Branch, RAS. 274 p. (In Russ.)

Sokolovskii, S. V. (2016) Vmesto vvedeniia. Teorii veshchei i etnografii material'nosti [In place of an introduction. Theories of objects and ethnographies of materiality]. In: Rossiiskaia antropologiia $i$ «ontologicheskii povorot» [Russian anthropology and the 'ontological turn'] / ed. S. V. Sokolovskii. Moscow, Institute of Ethnology and Anthropology RAS. 404 p. Pp. 3-30. (In Russ.)

Eticheskii kodeks IKOM dlia muzeev [ICOM Ethical Code for Museums]. ICOM [online] Available at: https://icom.museum/wp-content/uploads/2018/07/code_russia2013-1.pdf (access date: 01.03.2019). (In Russ.)

Alderton, Z. (2014) The Secular Sacred Gallery: Religion at Te Papa Tongarewa. In: Secularisation: New Historical Perspectives / Ch. Hartney (ed.). Newcastle upon Tyne, Cambridge Scholars Press. Pp. 251-264.

Batty, Ph. (2016) Problems associated with the management of secret / sacred objects in Australia: the Melbourne Museum Experience. Baessler-Archiv. Beiträge zur Völkerkunde, no. 63, pp. 11-16.

Bennett, T. (2018) Museums, Power, Knowledge. Selected Essays. London, Routledge. 340 p.

Buggeln, G., Paine, C. and Plate, B. (2017) Religion in Museums. Global and Multidisciplinary Perspectives. London; New York, Bloomsbury. 265 p.

Chambers, I. and De Angelis, A. (2014). The Postcolonial Museum: the Arts of Memory and the Pressures of History. Farnham, Ashgate. $274 \mathrm{p}$.

Clifford, J. (1997) Routes. Travel and Translation in the Late Twentieth Century. Cambridge, Massachusetts, Harvard University Press. 416 p.

Curtis, N. (2010) Repatriation from Scottish Museums: Learning from NAGPRA. Museum Anthropology, no. 33(2), pp. 234-248.

de l'Estoile, B. (2007) Le Goût des Autres. De l'Exposition coloniale aux arts premiers. Paris, Flammarion. 454 p.

De Largy Healy, J. (2011) Pour une anthropologie de la restitution. Archives culturelles et transmissions des savoirs en Australie. Cahiers d'ethnomusicologie, no 24, pp. 45-62.

Del Re, Ch., Countryman, P. (1995) How would you mount a Rambaramp? American Institute for Conservation. Resources | Conservation Online [online] Available at: http://resources.conservation-us.org/wp-content/uploads/sites/8/2015/02/ osg003-02.pdf (access date: 01.03.2019).

Dudley, S. (2012) Museum Objects: Experiencing the Properties of Things. London, Routledge. 347 p.

Gell, A. (1998) Art and Agency. An Anthropological Theory. Oxford, Clarendon Press. 296 p.

Grimes, R. (1992) Sacred Objects in Museum Spaces. Studies in Religion / Sciences religieuses, no. 21(4), pp. 419-430.

Hirsch, F. (2005) Empire of Nations. Ethnographic Knowledge and the Making of the Soviet Union. Ithaca, Cornell University Press. 392 p. $252 \mathrm{p}$.

Hodder, I. (2012) Entangled. An Archaeology of the Relationships between Human and Things. London, Wiley-Blackwell.

Hoskins, J. (1998) Biographical Objects. How Things Tell the Stories of People's Lives. New York; London, Routledge. 213 p.

Ingold, T. (2011) Being Alive. Essays on Movement, Knowledge and Description. London, Routledge. 270 p.

Jenkins, T. (2011) Contesting Human Remains in Museum Collections. A Crisis of Cultural Authority. New York, Routledge. $174 \mathrm{p}$.

Kasarhérou, E. (2016). Indigenous perspectives on sacred objects and museums in Melanesia: the New Caledonia case. Baessler-Archiv. Beiträge zur Völkerkunde, no. 63, pp. 24-28.

Kirschenblatt-Gimblett, B. (1998) Destination Culture. Tourism, Museums, and Heritage. Berkeley, University of California Press. 326 p.

Kopytoff, I. (1986) The cultural biography of things: Commoditization as process. In: The social life of things: commodities in cultural perspective / Appadurai, A. (ed.). Cambridge, Cambridge University Press. 339 p. Pp. 64-91.

Kreinath, J. (2015) Museality. In: R. A. Segal and Von Stuckrad, K. Vocabulary for the Study of Religion. Vol. 2 (F-O). Leiden, Brill. 1842 p. P. 481-486.

Kreps, Ch. (2015) Appropriate museology and the "new museum ethics". Honoring diversity. Nordisk Museologi, no. 2 , pp. 4-16. 
Küchler, S. (2002) Malanggan: Art, Memory and Sacrifice. London, Bloomsbury. 256 p.

Lonetree, A. (2012) Decolonizing Museums. Representing Native America in National and Tribal Museums. Chapel Hill, University of North Carolina Press. 248 p.

Marstine, J. (2011) The contingent nature of the new museum ethics. In: Routledge Companion to Museum Ethics. Redefining Ethics for the Twenty-First Century / Marstine, J. (ed.). London : Routledge. 486 p. Pp. 3-25.

Minucciani, V. (2013) Religion and Museums. Immaterial and Material Heritage. Torino, Umberto Allemandi. 110 p.

Munn, N. (1986) The Fame of Gawa. A Symbolic Study of Value Transformation in a Massim (Papua New Guinea) Society. Cambridge, Cambridge University Press. 331 p.

O'Neill, M. (2017) Museums and the Repatriation of Objects, 1945-2015. In: Buggeln, G., Paine, C., and Plate, B. (eds.) Religion in Museums. Global and Multidisciplinary Perspectives. London-New York : Bloomsbury. 265 p. P. 99-109.

Paine, C. (2013) Religious Objects in Museums. Public Lives and Public Duties. London; New York, Bloomsbury. 192 p.

Sarr, F., Savoy, B. (2018) The Restitution of African Cultural Heritage. Toward a New Relational Ethics. restitutionreport2018.com [online] Available at: http://restitutionreport2018.com/sarr_savoy_en.pdf (access date: 01.03.2019).

Stanley, N. (2007) Can Museums become Indigenous? The Asmat Museum of Culture and Progress and Contemporary Papua. In: Stanley, N. (ed.) The Future of Indigenous Museums. Perspectives from the Southwest Pacific. New York, Berghahn Books. 272 p. Pp. 190-204.

Teryukova, E. (2014) Display of religious objects in museum space. Russian museum experience in the 1920s and the 1930s. Material Religion, no. 10 (2), pp. 255-258.

Turnbull, P. and Pickering, M. (2010) The Long Way Home. The Meaning and Values of Repatriation. New York, Berghahn Books. 224 p.

Tythacott, L. and Arvanitis, K. (2014) Museums and Restitution: New Practices, New Approaches. London; New York, Routledge. 224 p.

Submission date: 15.03 .2019 . 